\title{
PEMANFAATAN DAUN KELOR SEBAGAI CAMPURAN OLAHAN MAKANAN DAN MENGANTISIPASI VIRUS COVID-19
}

\author{
Siti Rahmadani Lubis ${ }^{1)}$, M. Alif Alfaruqi ${ }^{2)}$, Aan Kriswana Fasha ${ }^{3)}$, Nurul Intan \\ Manurung ${ }^{4)}$, Misrah $^{5)}$
}

\begin{abstract}
Abstrak
Daun kelor dapat diolah dalam berbagai produk makanan dan minuman seperti sayur bening, juice, omelet, keripik, nastar, donat, bakwan dan mie daun kelor. Selain itu, daun kelor dapat diolah sebagai makanan herbal. Saat ini, dengan adanya kondisi pandemik covid-19 di seluruh dunia, banyak alternatif bahan herbal yang dikonsumsi oleh masyarakat untuk menambah nutrisi tubuh agar dapat mencegah terjadinya penularan virus tersebut, salah satunya adalah daun kelor. Tanaman kelor memiliki nutrisi tinggi, seperti vitamin $\mathrm{C}$, kandungan kalsium, vitamin A, kandungan potasium, dan protein. Tujuan pelaksanaan kegiatan KKN ini adalah untuk memberikan informasi dan melakukan pendampingan kepada masyarakat dalam memanfaatkan tanaman kelor untuk mencegah covid-19, serta meningkatkan keterampilan masyarakat dalam pembuatan makanan herbal daun kelor dalam mencegah covid-19. KKN ini dilaksanakan di Desa Air Joman dengan runtutan kegiatan adalah sosialisasi pentingnya daun kelor, persiapan bahan baku pembuatan makanan herbal daun kelor, dan praktik pembuatan produk makanan herbal daun kelor. Hasil dari kegiatan ini adalah terlaksananya sosialisasi pemanfaatan daun kelor sebagai salah satu cara menambah imunitas tubuh dalam rangka mencegah virus dan dilaksanakannya praktik pembuatan campuran oalahan makanan dari daun kelor bersama Kepala Desa, mahasiswa dan dosen di Desa Air Joman.
\end{abstract}

Kata kunci: daun kelor; makanan herbal; mencegah covid-19.

\begin{abstract}
Moringa leaves can be processed in various food and beverage products such as clear vegetables, juice, omelette, chips, nastar, donuts, bakwan and Moringa leaf noodles. In addition, Moringa leaves can be processed as herbal froods. Currently, with the covid-19 pandemic conditions around the world, many alternative herbal ingredients are consumed by the public to increase body nutrition in order to prevent transmission of the virus, one of which is Moringa leaves. Moringa plants are high in nutrients, such as vitamin $\mathrm{C}$, calcium, vitamin A, potassium, and protein. The purpose of implementing this KKN activity is to provide information and, to provide assistance to the community in utilizing Moringa plants to prevent Covid-19, as well as to improve community skills in making Moringa herbal food to prevent Covid-19. This KKN was held at the in Air Joman Village, with a series of activities including the socialization of the importance of Moringa leaves, the preparation of raw materials for making herbal moringa foods, and the practice of manufacturing Moringa leaf herbal food products. The results of this activity were the socialization of the use of Moringa leaves as a way to increase immunity in order to prevent viruses and the practice of making Moringa leaf tea with village head, students and lecturers at Air Joman Village.
\end{abstract}

Keywords: herbal food; moringa leaves; prevents covid-19 


\section{PENDAHULUAN}

Dunia sedang dilanda dengan hadirnya wabah penyakit yang disebut Covid-19. Penyakit yang ditimbulkan oleh infeksi virus SARS-CoV-2 tersebut pertama kali teridentifikasi di Kota Wuhan, Provinsi Hubei Cina pada bulan Desember 2019. Covid-19 sebelumnya dikenal sebagai Novel Coronavirus, sebelum WHO me- nyatakan nama secara resmi sebagai Covid-19 pada bulan Februari 2020 (Huang, Wang, Li, Ren, Zhao, \& Hu, 2020; Wu, Chen, \& Chan, 2020; \& Putri, 2020). Pada tanggal 30 Januari 2020, WHO menyatakan bahwa virus corona 20192020 sebagai Kesehatan Masyarakat Darurat Internasional (PHEIC), dan menyatakan pandemik pada 11 Maret 2020. Hampir 200 negara di dunia tertular virus corona, dan Indonesia adalah salah satu negara yang mengalami (Supriatna, 2020). Penyebaran Covid-19 sangat cepat dan angka kematian terus meningkat berbagai negara termasuk Indonesia. Kasus terinfeksi virus korona di Indonesia bertambah secara cepat, dilaporkanhingga Juni 2020 terdapat 31.186 kasus positif dan 1.851 kasus meninggal (PHEOC Kemenkes RI, 2020). DKI Jakarta merupakan provinsi dengan kasus covid- 19 tertinggi yaitu sebesar 7.623 kasus dan 523 $(6,9 \%)$ kasus kematian (PHEOC Kemenkes RI, 2020; lihat Putri, 2020). Penularan yang terjadi secara langsung antar manusia menimbulkan penambahan kasus positif yang banyak, misalnya akhir Januari 2020 dilaporkan terjadinya penambahan 2.000 kasus terkonfirmasi dalam 24 jam (Handayani, Hadi, Isbaniah, Burhan, \& Agustin, 2020). Virus corona diperkirakan dapat ditularkan melalui cairan yang dihasilkan dari batuk, bersin, menyentuh permukaan yang telah terkontaminasidan selanjutnya menyentuh area wajah maupun kontak lansung melalui ciuman dan berjabatan tangan. Gangguan pernapasan, demam, batuk dan sesak napas merupakan gejala awal terinfeksi Covid19. Pernapasan akut, Pneumonia, gagal ginjal, dan bahkan kematian adalah penyebab yang ditimbulkan pada kasus Covid-19 dengan gejala berat (Wulandari, Rahman, Pujianti, Sari, Laily, Anggraini, \& Prasetio, 2020). Menghadapi penyebaran covid-19 yang terus meningkat, maka tindakan pecegahan terus dilakukan. Salah satu himbauan pemerintah dalam rangka melindungi diri dari terjangkitnya virus adalah menjaga imun tubuh. Tubuh yang berimun tinggi, mengurangi risiko terjangkitnya berbagai virus. Salah satu cara pencegahan yang dapat dilakukan yaitu dengan mengkonsumsi minuman herbal yang terbuat dari bahan lokal yang terdapat disekitar kita dalam bentuk juice, jamu, seduhan teh maupun dalam bentuk lainnya.

Daun kelor merupakan salah satu bahan makanan herbal yang saat ini sedang ramai diperbincangkan baik dari kalangan pemerintah maupun masyarakat dan dianjurkan untuk dikonsumsi selama masa darurat covid-19. Daun kelor (Moringa oleifera Lamk.) merupakan tanaman yang kandungan nutrisinya sangat banyak dan semua bagian tanaman kelor sangat berguna bagi tubuh dan juga dapat meningkatkan ekonomi keluarga (Jusnita \& Syurya, 2019).

Selain nutrisi tanaman kelor banyak, kelor juga adalah jenis tanaman yang terdapat banyak antioksidan. Antioksidan pada tanaman kelor merupakan salah satu yang paling menonjol, terutama pada bagian daun. Menurut (Yuliani \& Dienina, 2015) antioksidan dapat mencegah pengaruh ancaman radikal bebas atau Reactive Oxygen Species yang terbentuk sebagai hasil dari metabolisme oksidatif yaitu hasil dari reaksi-reaksi kimia dan proses metabolik yang terjadi dalam tubuh. (Rahmawati \& Adi, 2016) menyatakan dalam penelitiannya bahwa satu gram daun kelor kering mengandung vitamin A 10 kali lebih banyak dari wortel, kalsium 17 kali lebih banyak dari susu, zat besi 25 kali 
lebih banyak dari bayam, protein 9 kali lebih banyak dari yogurt, dan potassium 15 kali lebih banyak dari pisang.

Berdasarkan dengan pertimbangan kondisi darurat covid-19, Universitas Islam Negeri Sumatera Utara juga merasa sangat penting untuk berpartisipasi dalam menyalurkan ilmu tentang pencegahan covid-19 khususnya dalam pemanfaatan tanaman obat melalui kegiatan Kuliah Kerja Nyata. Kegiatan ini dilakukan oleh para mahasiswa-mahasiswi UIN SU Kelompok 112 dengan judul "Pemanfaatan Daun Kelor Sebagai Campuran Olahan Makanan Dan Mengantisipasi Virus Covid-19”.

\section{METODE}

Kegiatan KKN dilaksanakan di Desa Air Joman,Kecamatan Air Joman Kabupaten Asahan. Kegiatan ini dilakukan dengan melibatkan Kepala Desa, dan juga Dosen sebagai DPL (Dosen Pembimbig Lapangan). Penentuan lokasi KKN di Desa Air Joman, kecamatan Air Joman Kabupaten Asahan diawali dengan survei yang dilakukan oleh mahasiswa untuk mengetahui potensi dan permasalahan yang terjadi di Desa Air Joman. Hasil survey menunjukkan bahwa Kepala Desa dan Masyarakat Desa Air Joman, Kecamatan Air Joman Kabupaten Asahan sangat antusias dengan program sosialisasi dan pembuatan produk olahan makanan dari daun kelor yang akan dilaksanakan, sekaligus penanaman daun kelor bersama Kepala Desa dan juga DPL (Dosen Pembimbing Lapangan) karena di Desa ini belum pernah melakukan budidaya daun kelor memanfaatkan dengan baik atau belum melakukan inovasi-inovasi produk dari dalam kelor yang dapat menambah nilai jual dari daun tersebut.

Pandemi covid-19 juga merupakan bentuk pertimbangan dalam mengolah daun kelor menjadi campuran olahan makanan herbal karena kandungan nutrisi dan antioksidannya yang sangat berguna dalam pencegahan penularan covid-19. Berdasarkan hasil survey tersebut, maka Dosen Pembimbing Lapangan (DPL) Kelompok KKN DR-112 Universitas Islam Negeri Sumatera Utara bersama mahasiswa UIN SU Kelompok 112 untuk melaksanakan sosialisasi kepada masyarakat terkait pemanfaatan dan inovasi produk daun kelor menjadi salah satu olahan campuran makanan herbal dengan tujuan untuk mencegah penyebaran covid-19 sekaligus meningkatkan ekonomi masyarakat.

Kegiatan ini memiliki konsep dasar yaitu memanfaatkan daun kelor sebagai salah satu olahan minuman herbal untuk menambah imun tubuh dan mencegah penyebaran virus. Tahapan-tahapan pelaksanaan KKN yaitu; pertama, survei lokasi dan kesepakatan waktu pelaksanaan kegiatan yang dilakukan oleh pihak Universitas Islam Negeri Sumatera Utara, Dosen Pembimbing Lapangan (DPL) dan kelompok KKN-DR 112. Kedua, sosialisasi dan penyampaian materi yang dilakukan oleh Dosen Pembimbing Lapangan (DPL). Materi yang disosialisasikan adalah teknik budidaya tanaman kelor, kegunaan daun kelor, dan teknik pembuatan makanan dengan campuran daun kelor sebagai makanan herbal. Ketiga, pendampingan dan latihan bersama tentang cara penyortiran serta persiapan daun kelor siap pakai. Kegiatan ini dilakukan oleh Kepala Desa Air Joman, Dosen Pembimbing Lapangan (DPL), dan juga mahasiswa UIN SU KKN-DR 112 dalam proses mempersiapkan bahan untuk pembuatan makanan herbal dari daun kelor. Kegiatan penanaman daun kelor dilaksanakan Dosen Pembimbing Lapangan (DPL) bersama Kepala Desa Air Joman, dan disaksikan oleh para mahasiswa-mahasiswi Universitas Islam Negeri Sumatera Utara Kuliah Kerja Nyata 
Dari Rumah (KKN-DR) kelompok 112.

\section{HASIL DAN PEMBAHASAN}

\section{Proses Pembuatan Minuman Herbal Dari Daun Kelor}

Siapkan \pm 100 gr daun kelor kering dan rebus dalam 2 liter air (wadah perebusannya dibiarkan terbuka). Biarkan mendidih selama 30 menit, kemudian tambahkan gula jawa dan potongan batang sereh secukupnya. Jika telah matang, lakukan penyaringan agar diperoleh oleh air rebusan yang jernih. Siap disajikan (dapat dikonsumsi dalam keadaan hangat maupun dingin menggunakan es batu).

\section{Daun Kelor Sebagai Campuran Berbagai Olahan Makanan}

\section{Mie Daun Kelor}

\section{Proses Pembuatannya :}

Pertama, campur tepung terigu dan garam dalam wadah. Kedua, tambahkan telur. Uleni sambil ditambah sari daun kelor sedikit demi sedikit. Uleni sampai merata dan menyatu. Tidak perlu sampai kalis/halus. Ketiga, potong-potong adonan menjadi beberapa bagian. Kemudian giling menggunakan pasta maker dengan ketebalan yang diinginkan. Keempat, giling beberapa kali sampai halus dan lembut. Kemudian potong-potong sesuai selera (saya potong pakai pasta maker dengan ukuran kecil). Rebus selama 3 menit. Setelah ditiriskan tambah sedikit minyak agar tidak lengket. Mie daun kelor homemade siapdigunakan untuk mie ayam atau masakan sesuai selera.

\section{Stik Daun Kelor}

\section{Bahan :}

- 50 gram daun kelor (petik daunnya saja)

- $100 \mathrm{ml}$ air

- 250 gram terigu serbaguna

- 25 gram tapioka

- 5 siung bawang putih, dihaluskan
- 50 gram margarin

- 1 butir telur

- 1/4 sdt garam

- 2 sdt kaldu bubuk

Proses Pembuatannya :

a. Haluskan daun kelor, saring, dan ambil sarinya.

b. Campur rata sari daun kelor, terigu, bawang putih halus, margarin, telur, garam, kaldu bubuk. Uleni hingga halus atau kalis.

c. Ambil sebagian adonan, pipihkan dan potong tipis memanjang. Taburi tepung sebelum adonan digiling dan dipotong agar tidak lengket.

d. Goreng stik daun kelor hingga matang dan kering.

e. Stik daun kelor siap disajikan, Simpan di tempat tertutup agar stik tetap renyah.

\section{Bakso Daun Kelor}

\section{Bahan :}

- 100 gram daun kelor, cincang halus

- 100 gram daging ayam, cincang

- $1 / 2$ sdt merica bubuk

- $1 / 2$ sdt garam

- 2 sdm tepung tapioka

- Es batu secukupnya

- 1 butir telur

- 100 gram jamur ( tergantug selera, boleh pakai atau tidak)

- 100 gram mihun jagung

- Air secukupnya

- 1 batang daun seledri

- 1 batang bawang prei, potong $2 \mathrm{~cm}$

- $750 \mathrm{ml}$ air kaldu ayam

- $1 \mathrm{sdm}$ minyak goreng

- 5 siung bawang putih

- $1 / 2$ sdt merica bubuk

- 1/2 sdt gula pasir

- 1 sdt garam

- 8 siung bawang merah

- 1 biji buah pala

- Tulang ayam untuk kaldu

Proes Pembuatannya : 
a. Giling daging ayam dan daun kelor dengan blender bersama dengan es batu secukupnya.

b. Campuran adonan daging dan daun kelor dicampur dengan tepung tapioka, garam, telur, serta merica kemudian diuleni hingga halus atau kalis.

c. Adonan daging kelor dibentuk bulat seperti pentolan bakso pada umumnya.

d. Masukkan pentolan bakso daun kelor yang telah dibentuk ke dalam air yang mendidih.

e. Untuk kuah bakso, siapkan kaldu ayam dari tulang daging, masukkan dalam panci kemudian didihkan.

f. Masukkan bumbu kuah bakso ke dalam panci, tambahkan gula dan garam secukupnya serta sawi hijau ( sesuai selera).

g. Siapkan miehun jagung yang sudah direbus ke dalam mangkuk.

h. Masukkan bakso daun kelor ke dalam mangkuk dan siram dengan kuah bakso yang sudah disiapkan sebelumnya.

i. Bakso daun kelor siap dihidangkan dan dinikmati.

\section{Sayur Bening Daun Kelor}

\section{Bahan :}

- Daun kelor petik dan ambil daunnya saja.

- 1 buah jagung, potong-potong.

- 5 buah bawang merah, potong tipistipis

- 2 ruas jahe, cuci bersih

- $1500 \mathrm{ml}$ air

- Bawang goreng untuk taburan (tergantung selera, boleh pakai atau tidak)

Proses Pembuatannya :

a. Rebus jagung, bawang merah dan kunyit hingga matang. Beri garam dan gula secukupnya.

b. Masukkan daun kelor. Masak sebentar saja.

c. Angkat dan sajikan dengan bawang goreng.

\section{Kue Kering Daun Kelor}

\section{Bahan :}

- 250 gram margarin

- 500 gram sagu

- 200 gram gula putih ( dihaluskan)

- 1 atau 2 tetes vanilla essence

- 2 kuning telur

- $1 / 2$ saset santan instan

- 90 gram keju parut

- 50 gram susu bubuk

- 50 gram daun kelor yang saudah di haluskan

\section{Proses Pembuatannya :}

a. Sangrai sagu, setelah itu diamkan hingga dingin.

b. Kocok margarin dengan gula halus, masukkan telur satu persatu kocok terus sampai mengembang.

c. Masukkan keju parut, susu, vanilla essence 1 tetes, kocok pelan-pelan, terakhir masukkan sagu dan daun kelor yang sudah di haluskan menjadi bubuk, aduk hingga merata.

d. Olesi loyang dengan margarin, masukkan adonan ke dalam weaping bag / plastik segitiga dengan spuit bintang, cetak di atas loyang yang sudah di olesi margarin.

e. Panggang dengan oven kurang lebih 12-15 menit atau sampai sudah kering. Lalu di angkat dan dinginkan.

$f$. Kue kering daun kelor siap disajikan.

\section{Telur Kukus Daun Kelor}

\section{Bahan :}

- 5 butir telur ( ambil putihnya saja )

- 2 kuning telur

- 2 cabai merah, iris

- $1 / 2$ tomat, iris

- 2 siung bawang merah, iris

- 1 genggam tangan daun kelor

- Garam dan kaldu jamur secukupnya

Proses Pembuatannya : 
a. Campur semua bahan menjadi satu seperti membuat telur dadar.

b. Kukus hingga matang atau mulai mengeras

c. Telur kukus daun kelor siap disajikan.

\section{Bolu Daun Kelor}

\section{Bahan :}

- Daun kelor di blender secukupnya.

- 6 sdm terigu

- 2 butir telur

- 6 sdm gula pasir

- 6 sdm susu kental manis

- 1 sdt baking powder

- 1 saset vanili

\section{Proses Pembuatannya :}

a. Kocok telur dan gula hingga gula larut.

b. Masukkan daun kelor yang telah di blender.

c. Masukkan tepung terigu dengan cara di ayak sedikit demi sedikit dan tambahkan susu, baking powder dan vanili, aduk rata, tes rasa.

d. Siapkan peralatan untuk mengukus. Masukkan adonan ke dalam cetakan yang telah di olesi margarin. Kukus hingga matang.

e. Siap untuk disajikan.

\section{Daun Kelor Efektif Meningkatkan Imunitas Tubuh Untuk Mengantisipasi Virus Covid -19}

Selama ini masyarakat Indonesia mengenal daun kelor sebagai tanaman penangkal mistis. Namun, daun kelor juga diyakini mampu meningkatkan sistem kekebalan tubuh, yang sangat bermanfaat pada masa pandemi virus covid 19 seperti sekarang ini. Seperti diketahui, dengan kekebalan tubuh yang baik, potensi terpapar virus corona atau vovid 19 bisa makin kecil.

Selama ini, masyarakat juga memanfaatkan daun kelor sebagai bahan makanan seharihari.

Dilansir dari WHO, mengonsumsi daun kelor membantu perkembangan tubuh dan menjadi bahan obat tradisional untuk mengobati berbagai penyakit. Daun kelor kaya akan vitamin A, vitamin B1 (tiamin), vitamin B2 (riboflavin), vitamin B3 (niacin), vitamin $\mathrm{B} 6$, serta vitamin $\mathrm{C}$, mineral, dan senyawa tanaman bermanfaat lainnya.

Selain itu, kandungan polifenol dalam daun kelor memiliki sifat melawan kanker dan dapat mengurangi resiko seperti penyakit jantung dan diabetes. Daun kelor bisa dikonsumsi secara mentah, diolah menjadi the, hingga menjadi berbagai olahan makanan. Daun kelor juga memiliki kandungan penting lainnya seperti kalsium, kalium, zat besi, magnesium, fosfor, seng, serta rendah kalori.

WHO sampai menjuluki daun kelor sebagai miracle tree karena khasiat yang terkandung di dalamnya. Semua senyawa tersebut sangat diperlukan bagi kesehatan tubuh. Nutrisi yang dimiliki daun kelor, membuat manfaat tanaman ini selalu diminati pencinta herbal.

Tidak hanya itu, daun kelor juga dapat meningkatkan sistem kekebalan tubuh untuk mencegah atau mengantisipasi virus covid-19. Daun kelor merupakan tanaman yang memiliki berbagai manfaat yang baik untuk tubuh, kandungan antioksidan dan asam amino pada daun kelor tidak hanya meningkatkan daya tahan tubuh, melainkan dapat memperbaiki segala kerusakan yang dapat disebabkan oleh virus.

\section{Agen Antioksidan}

Daun kelor memiliki sifat antioksidan yang mampu melindungi tubuh dari serangan radikal bebas. Sifat antioksidan yang tinggi mampu meningkatkan daya tahan tubuh lebih kuat sehingga mampu menangkal berbagai penyakit, seperti virus covid-19 seperti sekarang ini.

2. Agen Antibakteri

Selain memiliki sifat antioksida, 
daun kelor juga memiliki sifat antibakteri. Sifat antibakteri yang ada dalam daun kelor mampu menghambat perkembangan mikroorganisme berbahaya yang ada dalam tubuh. Mikroorganisme yang berkembang dalam tubuh mampu merusak jaringan dalam tubuh dan menimbulkan berbagai gangguan kesehatan.

3. Mengatasi Peradangan

Mengonsumsi daun kelor mampu meredakan peradangan yang ada di dalam tubuh. Kandungan isotiosianat yang berperan sebagai zat antiinflamasi.

4. Meningkatkan Sistem Kekebalan Tubuh

Selain berguna untuk mengatasi stres, kandungan asam amino pada daun kelor juga berperan penting untuk menjaga sistem pencernaan tubuh. Kandungan nutrisi yang ada dalam daun kelor berfungsi efektif memperbaiki segala kerusakan pada jaringan tubuh dan proses pertumbuhan. Rutinitas mengonsumsi daun kelor, kita akan memiliki sistem kekebalan tubuh yang kuat dan terhindar dari risiko terjangkit berbagai penyakit, termasuk untuk mencegah atau mengantisipasi diri dari virus covid-19.

\section{Kegiatan Menanam Pohon Kelor DPL Bersama Kepala Desa Air Joman}

\section{Melalui Teknik Pembibitan Biji Kelor}

Ada dua cara yang bisa kamu gunakan ketika mulai menanam tanaman kelor di rumah. Cara tersebut adalah melalui teknik pembibitan biji kelor dan melalui teknik stek batang kelor. Cara menanam menggunakan teknik pembibitan biji kelor cocok digunakan karena lebih produktif, tahan penyakit, dan bisa hidup sampai usia 50 tahun. Namun, proses penanaman menggunakan teknik pembibitan membutuhkan waktu yang lebih lama dibandingkan dengan melalui teknik stek batang. Berikut adalah cara menanam pohon kelor melalui teknik pembibitan:

- Pertama pilih biji kelor berkualitas dan jemur biji di bawah sinar matahari selama sekitar 1 jam.

- Rendam biji di air hangat kemudian pilih biji yang mengapung di air untuk ditanam.

- Siapkan tempat penyemaian, seperti polybag, lalu campurkan tanah dan pupuk kandang ke dalam polybag.

- Semai biji di dalam polybag lalu simpan media semai di tempat teduh dan siram secara rutin.

- Ketika kecambah mulai tumbuh atau sudah mencapai usia 7-12 hari, pindahkan bibit ke polybag yang berukuran lebih besar sampai bibit dapat dipindahkan ke lahan permanen.

\section{Melalui Teknik Stek Batang Kelor}

Teknik ini merupakan teknik yang paling sering digunakan oleh masyarakat Indonesia karena proses penanamannya yang cepat. Namun, pohon kelor yang ditanam melalui teknik stek lebih rentan akan penyakit dan hanya hidup sampai usia 30-40 tahun saja. Berikut adalah cara menanam pohon kelor melalui teknik stek batang:

- Siapkan batang kelor yang sudah dipotong dengan ukuran mencapai 30$50 \mathrm{~cm}$ dan diameter $3-5 \mathrm{~cm}$.

- Potong batang secara mendatar agar dapat tumbuh akar lebih cepat dan lebih banyak.

- Potong tangkai yang akan dijadikan bibit dan masukkan tangkai ke dalam polybag berisi campuran tanah dan pupuk kandang.

- Letakkan polybag di area yang teduh dan siram secara rutin. 


\section{Proses Penanaman Pohon Kelor}

Setelah bibit mulai tumbuh dan membesar, sudah waktunya kamu memindahkan bibit dari media semai ke lahan terbuka. Proses penanaman ini cukup mudah untuk dilakukan. Pertama buat lubang berukuran 40×40 dengan kedalaman $30-40 \mathrm{~cm}$ sebagai tempat ditanamnya pohon kelor. Isi lubang menggunakan pupuk kandang dan biarkan selama 1 minggu sebelum proses penanaman pohon kelor. Setelah 1 minggu, masukkan bibit pohon kelor yang telah berukuran 30$50 \mathrm{~cm}$ ke dalam lubang. Padatkan tanah agar pohon kelor dapat berdiri tegak dan siram secara rutin.

\section{SIMPULAN}

Kegiatan Kuliah Kerja Nyata Dari Rumah (KKN-DR) Kelompok 112 dilakukan untuk memberikan pemahaman, mengimplementasikan proses penanaman pohon kelor kepada masyarakat di Desa Air Joman Kecamatan Air Ba Kabupaten Asahan. Kegiatan sosialisasi dan penanaman daun kelor diikuti secara antusias oleh masyarakat, Kelompok 112 KKN-DR UIN SU, Dosen Pembimbing Lapangan (DPL), dan juga Kepala Desa Air Joman Kecamatan Air Joman Kabupaten Asahan dari awal kegiatan sampai akhir kegiatan

\section{DAFTAR PUSTAKA}

Handayani, D., Hadi, D. R., Isbaniah, F., Burhan, E., \& Agustin, H. (2020). Corona virus disease 2019. Jurnal Respirologi Indonesia.

Huang, C., Wang, Y., Li, X., Ren, L., Zhao J., \& Hu, y. (2020). Clinical features of patients infected with 2019 novel coronavirus in Wuhan, China., Lancet, Doi.

Jusnita, N., \& Syurya, W. (2019). Karakterisasi Nanoemulsi Ekstrak Daun Kelor (Moringa oleifera Lamk.). Jurnal Sains Farmasi \& Klinis, Vol. 6 No. 1 (April 2019).
Putri, R Ni. (2020). Indonesia dalam Menghadapi Pandemi Covid-19. Jurnal Ilmiah Universitas Batanghari Jambi, 20(2), Juli 2020.

Rahmawati, P. S., \& Adi, A C. (2016). Daya Terima dan Zat Gizi Permen Jeli Dengan Penambahan Bubuk Daun Kelor (Moringa oleifera). Media Gizi Indonesia, Vol. 11, No. 1

Suprianta, E. (2020). Wabah Corona Virus Disease Covid 19 Dalam Pandangan Islam. Salam: Jurnal Sosial dan Budaya Syar-i. Volume 7 Nomor 6 (2020).

Wulandari, A., Fauzie, R., Nita, P., Ayu, R. S., Nur, L., Lia, A., Farid, I. M., Agus, M. R., Vina, Y. A.,

Muhammad, A., \& Diki, B. P. (2020). Hubungan Karakteristik Individu Dengan Pengetahuan tentang Pencegahan Coronavirus Disease 2019 pada Masyarakat di Kalimantan Selatan. Jurnal Kesehatan Masyarakat Indonesia, Volume 15, Nomor 1, 2020.

Yuliani, N. N., \& Desmira, P. D. (2015). Uji Aktivitas Antioksidan Infusa Daun Kelor (Moringa oleifera, Lamk) dengan Metode1,1- diphenyl- 2-picrylhydrazyl (DPPH). Jurnal Info Kesehatan, vol. 14, nomor 2 desember 2015. 